\title{
DAMPAK SOSIAL KEBERADAAN INDUSTRI TERHADAP MASYARAKAT SEKITAR KAWASAN INDUSTRI CILEGON
}

\author{
SOCIAL IMPACTS OF INDUSTRIAL EXISTENCE \\ TO THE COMMUNITIES AROUND CILEGON INDUSTRIAL ESTATE
}

\author{
Yunia Rahayuningsih \\ Badan Perencanaan dan Pembangunan Daerah Provinsi Banten \\ Jl. Syech Nawawi Al Bantani, (KP3B) Serang, Banten \\ Tlp. (0254) 267053 fax. (0254) 267052 \\ E-mail: yuniarahayuningsih@gmail.com
}

\begin{abstract}
ABSTRAK
Industrialisasi merupakan salah satu bentuk pendorong menuju modernisasi yang diharapkan dapat meningkatkan taraf hidup masyarakat. Perubahan pembangunan yang pesat akibat industri selain akan meningkatkan kesejahteraan masyarakat, juga akan berdampak langsung pada kehidupan sosial budaya masyarakat setempat. Seperti dua sisi mata uang logam yang berbeda, memiliki dampak positif dan negatif tertentu bagi masyarakat sekitar. Oleh karena itu, perkembangan kawasan industri harus memperhitungkan dampaknya. Penelitian ini bertujuan untuk: 1) mendapatkan gambaran terkait potensi dan sumberdaya masyarakat sekitar kawasan industri; 2) mendapatkan gambaran mengenai dampak positif dan negatif keberadaan industri terhadap masyarakat sekitar kawasan. Penelitian ini menggunakan mixed methode, dan pengambilan sampel dengan menggunakan teknik purposive random sampling. Hasil penelitian menunjukkan bahwa: 1) Kota Cilegon memiliki kekuatan sumber daya alam dan sumber daya manusia yang potensial menunjang pembangunan sosial ekonomi wilayahnya dalam mencapai kesejahteraan masyarakat sekitarnya; 2) dampak positif kawasan industri diantaranya mengurangi pengangguran, terbuka peluang usaha, kesempatan kerja, dan peningkatan kualitas kesejahteraan masyarakat. Sedangkan dampak negatif yang ditimbulkan antara lain lingkungan tercemar, kemacetan lalu lintas, terjadinya kasus-kasus kriminal, menimbulkan kesenjangan, masyarakat bergaya konsumtif, dan pergeseran nilai-nilai luhur budaya masyarakat setempat.
\end{abstract}

Kata Kunci: Dampak Sosial, Industri, Kawasan Industri, Masyarakat

\section{ABSTRACT}

Industrialization has long been believed as one of key drivers toward modernization, which is expected to improve people's lives. Rapid development advancement due to industrialization, in addition to the improvement of the community's welfare, on one hand, will also have direct impacts on the socio-cultural life of local communities on the other. Like two sides of a coin, it has certain positive and negative impacts to the surrounding communities. The development of industrial estate, therefore, needs to consider these impacts. In relation to the growth of industrial estate in Cilegon City, this study aims to: 1) get an overview of the potential of community resources surrounding the industrial area; 2) explore the positive and negative impacts of industrial presence on the surrounding communities. This research employs a mixed method, and 
purposive random sampling technique was applied for data collection. The study found that: 1) Cilegon city benefits from natural resources and potential human resources to support the socioeconomic development of its territory in achieving the welfare of the surrounding community; 2) the industrial estate has positive impacts, such as reducing unemployment, enhancing SMES opportunities, creating more job opportunities, and improving the quality of community welfare. The negative impacts, on the other side, include polluted environments, traffic congestion, the occurrence of criminal cases, causing social inequalities, consumptive-style society, and a shift in the noble values of local culture.

Keywords: Social Impact, Industry, Industrial, Community Impacts

\section{PENDAHULUAN}

Kota Cilegon merupakan salah satu kota industri yang strategis di Provinsi Banten. Hal ini disebabkan posisi kota ini sebagai kota industri dengan pusat-pusat industri khususnya di bagian barat kota.

Terkait dengan kawasan industri, percepatan pengembangan dilakukan agar pembangunan di suatu wilayah dapat dicapai secara cepat, tepat, tertib, dan teratur. Oleh karena itu, seiring pengembangan kawasan industri di suatu wilayah, tetap perlu mengindahkan peraturan pemerintah yang terkait dengan lingkungan kawasan industri maupun masyarakat sekitar yang akan memperoleh dampak langsung akibat berdirinya kawasan industri di sekitar pemukiman mereka. Seperti dua sisi mata uang logam yang berbeda, pengembangan kawasan industri memiliki dampak positif dan negatif tertentu bagi masyarakat sekitar.
Dalam rangka memperoleh data yang akurat dan tepat, mengenai potret kondisi existing masyarakat yang berada di sekitar kawasan industri, serta mengantisipasi dampak negatif, baik secara ekonomi, sosial, budaya dan kemasyarakatan, maka perlu adanya penelitian dampak sosial keberadaan industri terhadap masyarakat sekitar kawasan industri Kota Cilegon. Tujuan penelitian ini yaitu: (1) Mendapatkan gambaran terkait potensi dan sumberdaya masyarakat sekitar kawasan industri; (2) Mendapatkan gambaran mengenai dampak positif dan negatif keberadaan industri terhadap masyarakat sekitar kawasan.

\section{METODE PENELITIAN}

Lokasi penelitian yaitu di Kota Cilegon, dipilih 2 lokus penelitian (Kecamatan Cilegon dan Ciwandan) yang merupakan kawasan industri. Penelitian ini 
menggunakan mixed method dan menggunakan teknik purposive random sampling, yaitu teknik pengambilan sampel dengan pertimbangan tertentu (Sugiyono, 2013:122). Teknik ini termasuk dalam kategori probability and non probability sampling, yaitu teknik pengambilan sampel yang tidak memberikan peluang atau kesempatan sama bagi setiap unsur atau anggota populasi untuk dipilih menjadi sampel (Sugiyono, 2013: 120).

Penelitian ini menggunakan dua jenis data yaitu data primer dan data sekunder. Data dan informasi diperlukan antara lain: (1) Kondisi fisik penelitian yang berada di sekitar kawasan industri; (2) Potensi sumberdaya yang ada di Kota Cilegon; (3) Keragaman dampak sosial masyarakat di sekitar kawasan industri. Adapun data primer dikumpulkan melalui: 1) Observasi, untuk mengamati kondisi dampak keberadaan kawasan industri, dan 2) Angket dan Kuesioner digunakan untuk memperoleh data primer dari masyarakat.

Teknik analisis yang digunakan dalam penelitian adalah analisis statistik melalui pendekatan deskriptif kuantitatif. Analisis deskriptif kuantitatif digunakan untuk menjelaskan dan mendeskripsikan karakteristik dan sejarah industri, karakteristik responden, dampak industri terhadap kondisi fisik (perubahan pengunaan lahan, ketersediaan fasilitas umum dan kondisi prasarana jalan), kondisi lingkungan (kebisingan, pencemaran udara dan pencemaran air), serta kondisi sosial ekonomi. Selanjutnya, penelitian juga menggunakan kerangka analisis model interaktif Miles dan Huberman (1992:16) guna menganalisis informasi selama penelitian berlangsung.

\section{HASIL DAN PEMBAHASAN}

Potensi dan Sumberdaya Masyarakat

\section{Sekitar Kawasan Industri}

Kota Cilegon dikenal sebagai kota perindustrian dan merupakan pusat perindustrian di kawasan Banten bagian barat yang memiliki berbagai sarana dan prasarana pendukung diantaranya jalan darat, dua pelabuhan yaitu Pelabuhan Banten-Merak dan Pelabuhan Karangantu, serta dukungan sarana pembangkit tenaga listrik, air, gas, dan telekomunikasi.

Letak geografis Kota Cilegon yang strategis memberikan nilai tambah di mata investor asing maupun dalam negeri. Akses jalur darat, laut dan udara yang mendukung dalam proses distribusi baik pengiriman bahan baku dan barang jadi menjadi suatu tolak ukur dalam perencanaan investasi 
dalam menetapkan lokasi proyek investasi yang dapat memberikan nilai ekonomis penurunan biaya transportasi dan penyediaan kebutuhan bahan baku serta pengiriman barang jadi secara just in time. Selain itu iklim usaha yang kondusif serta dukungan Pemerintah Kota Cilegon terhadap perkembangan industri skala besar memberikan nilai positif dalam berinvestasi di Kota Cilegon. Keberhasilan investasi Joint Venture antara PT. Krakatau Steel dengan PT. Pohang Steel Corporation asal Korea menjadikan pemicu perusahaan yang sudah ada di Kota Cilegon ikut memperluas usahanya seperti PT. Nippon Shokubai Indonesia, PT. Candra Asri, serta PT. Asahimas Petrochemical Indonesia.

Kota Cilegon sebagai daerah tujuan investasi memiliki daya tarik bagi investasi dalam dan luar negeri, hal ini dapat dilihat dari tingginya minat investor yang menanam modalnya di Kota Cilegon yang berasal dari USA, Perancis, Jepang, Australia, Jerman, Inggris, Argentina, Austria dan Korea. Kota Cilegon dengan daya tarik investasi kategori A mendapat penghargaan dari Komite Pemantau Pelaksanaan Otonomi Daerah. Hal ini merupakan indikator yang masih kondusif dan nyaman sebagai daerah tujuan investasi dengan pertumbuhan investasi pada 2006 mencapai 12,44\%. Kota Cilegon dengan luas lahan $17.550 \mathrm{Ha}(175,50 \mathrm{~km} 2)$ ditunjang dengan sarana prasarana yang cukup memadai serta letak geografis yang sangat strategis dengan jarak tempuh dari ibukota Jakarta $+120 \mathrm{~km}$, perjalanan selama 2 jam tentunya melalui akses jalan tol.

Kota Cilegon sebagai pintu gerbang pulau Jawa dan Sumatera, serta memilih garis pantai sepanjang $17 \mathrm{~km}$, didukung oleh pelabuhan bertaraf internasional dan adanya pelabuhan khusus, serta beberapa kawasan industri menjadikan Kota Cilegon sebagai tujuan investasi yang menarik bagi calon investaor. Kota Cilegon terbuka untuk investasi bidang usaha besi dan baja, kimia, plastik, manufacture, pariwisata, usaha aneka dan jasa-jasa lainnya.

Selain pembangunan fisik Kota Cilegon, pemerintah juga menjalankan berbagai kebijakan diantaranya:

a. Peningkatan daya saing yang kompetitif berbasis sumber daya dengan prioritas pada sektor industri kecil dan menengah.

b. Membudayakan program kemitraan antar pelaku ekonomi berdasarkan pola kemitraan untuk menidukung pertumbuhan otonomi daerah.

c. Menjadi fasilitator bagi pengembagan ekonomi daerah dan mendorong asosiasiasosiasi usaha lebih berdaya dan mandiri.

d. Bersama kalangan usaha berinovasi dan 
berprakarsa bagi penciptaan peluang usaha baru, pengembangan sentra industri kecil unggulan, serta pengembangan dan penataan sentrasentra perdagangan, baik skala lokal maupun regional.

e. Menciptakan iklim investasi yang kondusif dengan menyediakan pusat pelayanan terpadu satu atau atau one stop service.

f. Mengubah paradigma lama birokrasi pemerintahan menuju entrepreneurship birokrasi atau reinventing government.

Strategi Kota Cilegon dalam menarik investor, diantaranya dapat diuraikan sebagai berikut:

a. Adanya kepastian hukum dan keamanan.

b. Stabilitas ekonomi.

c. Akses ke ibukota Jakarta dan Pelindo II Bojonegara.

d. Kota Cilegon sebagai gerbang penghubung Jawa-Sumatera.

e. Adanya sarana dan prasarana pendukung investasi.

Untuk menarik investor tersebut Pemerintah Kota Cilegon dengan PT Krakatau Steel dan perusahaan lainnya menyediakan berbagai sarana prasarana pendukung untuk kegiatan investasi terutama dalam menyiapkan kawasan industri yang terdiri dari:

a. Kawasan Krakatau Industrial Estate

\section{Cilegon (KIEC I)}

Luas kawasan 550 Ha, luas kawasan yang sudah terjual 250,94 Ha, luas kawasan yang belum terjual 198,06 Ha, sarana \& prasarana 100,78 Ha.

b. Kawasan Krakatau Industrial Estate Cilegon (KIEC II)

Luas kawasan 80,9 Ha, sudah terjual 0,9 $\mathrm{Ha}$, belum terjual $80 \mathrm{Ha}$.

c. Kawasan Pancapuri $250 \mathrm{Ha}$.

d. Kawasan Cipta Niaga Internasional 22 Ha.

Sedangkan sektor industri kecil yang dikembangkan di wilayah pemerintahan Kota Cilegon, selain dianggap sebagai kota industri, juga memiliki industri kecil dan menengah yang tersebar di 9 kecamatan, yaitu industri kecil formal 262 unit dan industri kecil non formal 1.197 unit. Adapun yang menjadi sektor unggulan dari IKM antara lain sentra batu bata dan genteng 689 unit, sentra kasur 75 unit, dan sentra emping 1.7772 unit.

Untuk membantu pemberdayaan usaha kecil dan menengah yang ada di Kota Cilegon, dibentuk beberapa lembaga untuk memfasilitasi permasalahan di bidang permodalan, managemen dan pemasaran diantaranya lembaga inkubasi usaha kecil, lembaga perintis usaha, trading house, dan badan zakat infaq sadaqoh (Bazis). 
(Profil Kota Cilegon, 2016)

\section{Dampak Positif dan Negatif Keberadaan}

\section{Industri Terhadap Masyarakat Sekitar}

Keberadaan kawasan industri di wilayah Cilegon, memberikan dampak positif cukup signifikan, kecenderungan masyarakat menyambut baik akan keberadaan kawasan industri. Mereka merasakan banyak hal yang dapat mereka alami. Di samping mampu meningkatkan kualitas kesejahteraan masyarakat, membuka lapangan kerja bagi masyarakat di sekitar kawasan dan mengurangi pengangguran. Keterbatasan modal menjadi faktor utama bagi keberlanjutan usaha masyarakat, agar mereka dapat hidup layak dan lebih berdaya. Oleh karena itu, pemerintah perlu menggalang keterlibatan swasta, dalam hal ini perusahaan-perusahaan yang berada di kawasan industri untuk membuat program anak asuh bagi masyarakat yang memiliki semangat wirausaha atau sudah merintis usaha untuk mendapatkan bantuan dana pengembangan usaha.

Berdasarkan hasil penelitian, keberadaan perusahaan di Kota Cilegon menurut responden masih belum optimal. Diketahui bahwa mayoritas keberadaan perusahaan mendapat ijin dan dukungan pemerintah, namun tidak sedikit pula perusahaan yang tidak mendapat ijin dan dukungan pemerintah, sehingga pemerintah dalam hal ini harus melacak perusahaan yang tidak berijin, agar meminimal resiko yang berdampak pada lingkungan masyarakat sekitar. Kemudian, bila ditinjau dari kontribusi perusahaan terhadap kegiatan masyarakat untuk program jangka panjang, sampai saat ini mayoritas masyarakat masih meragukan kontribusi perusahaan yang ada di kawasan industri, bagi kemajuan masyarakat sekitarnya. Kepedulian perusahaan terhadap program pemberdayaan masyarakat yang berkelanjutan masih belum memadai. Dengan demikian, kegiatan corporate social responsibility perusahaan dapat dioptimalkan bagi kehidupan masyarakat yang makin berkualitas.

Selain itu, kegiatan yang dilaksanakan oleh perusahaan berkaitan dengan masyarakat, masih lemah dalam melakukan komunikasi dan koordinasi dengan masyarakat. Masih terdapat beberapa perusahaan yang memenuhi fasilitas pendukungnya diambil dari sekitar pemukiman warga. Hal ini dianggap menganggu kenyamanan dan keamanan kehidupan warga, dan dikhawatirkan bila tanah dikeruk terus, atau air yang digunakan dalam jumlah yang banyak, atau lainnya akan mengakibatkan rawan bencana. 
Kota Cilegon saat ini sedang menghadapi perubahan besar dengan masuknya industri Korea yang akan menggunakan tenaga kerja dari negara asal. Begitu banyak perusahaan asing di Kota Cilegon ini yang salah satunya adalah perusahaan-perusahaan dari Korea. Terkait hal tersebut, Gubernur mengharapkan terjalin kerjasama yang baik seperti dituangkan melalui MoU antara Pemerintah Provinsi Banten dengan Pemerintah Korea Selatan. Selanjutnya, Pemerintah Provinsi Banten berjanji akan berbicara dengan pihak Pemerintah Kota Cilegon untuk menindaklanjuti penerapan Kawasan Ekonomi Khusus (KEK) Krakatau-Posco yang diharapkan akan memberikan sumbangsih bagi peningkatan ekonomi masyarakat Banten.

Keberadaan kawasan industri dekat pemukiman warga mampu meningkatkan kesejahteraan sosial masyarakat. Berdasarkan hasil penelitian, diketahui bahwa kehadiran perusahaan membuka lapangan kerja, namun peluang masyarakat setempat mendapat pekerjaan relatif masih belum optimal, karena harus bersaing dengan para pendatang. Dampak positif yang betulbetul dirasakan masyarakat dengan keberadaan kawasan industri, adalah perusahaan membantu masyarakat tidak mampu, hal ini dinyatakan responden sebanyak $74 \%$ menyatakan setuju dan sangat setuju. Sedangkan peluang membuka usaha untuk memenuhi kebutuhan para pegawai, dan dengan bertambahnya para pendatang sebanyak 48\%. Tetapi dari beberapa responden sebanyak $52 \%$ menyatakan netral bahkan cenderung tidak setuju. Sesuai pernyataan responden yang setuju atau sangat setuju sebanyak $70 \%$ perusahaan yang berada di kawasan industri, membantu masyarakat tidak mampu. Pendapatan masyarakat meningkat dan peluang membuka usaha juga meningkat, terbukti sebanyak lebih dari 70\%.

Keberadaan kawasan industri, didukung dengan banyaknya pendatang yang terus bertambah, tidak selalu berdampak pada kriminalitas. Tetapi hal ini tetap perlu menjadi perhatian mengingat pernyataan netral dan cenderung tidak setuju bila kriminalitas tidak menimbulkan dampak negatif, yaitu sebanyak 50\%. Dengan adanya perkembangan kawasan industri, sebanyak $32 \%$ menyatakan masyarakat mengalami perubahan gaya hidup dari kehidupan yang sederhana menjadi konsumtif. Tetapi tidak sedikit pula masyarakat yang bertahan dengan gaya hidup sebelumnya, tanpa tergoyahkan oleh keadaan apapun. Mahalnya biaya hidup pun dengan adanya kawasan 
industri sebanyak $32 \%$ responden menyatakan sangat setuju dan setuju. Sedangkan pengelolaan lingkungan di kawasan industri dan sekitar sudah cukup baik, untuk menghindari polusi udara, bau tidak sedap, penghijauan akan berkurang, suara bising, sumber air bersih sulit, lalu lintas macet, juga dirasakan oleh sebagian responden. Namun masih ada sebagian warga yang masih merasakan hal ini, terbukti $6-42 \%$, terutama polusi udara yang perlu diimbangi dengan gerakan penghijauan.

Dampak negatif yang paling dirasakan dari keberadaan kawasan industri, tidak dapat dipungkiri dengan jumlah pendatang yang meningkat, persaingan kerja pun semakin meningkat, sehingga potensi timbulnya kriminalitas tidak dapat dihindari. Selain itu permasalahan yang terjadi di wilayah sekitar PT. Posco, PT. Nippon, dan PT. Sankyu, para pendatang terutama warga asing lebih mendominasi dibandingkan warga pribumi di sekitar kawasan industri (Mahfid, S.Pd Lurah Warnasari Cilegon). Gejala ini ditimbulkan karena adanya kesenjangan hidup pada masyarakat, sehingga timbul kecemburuan sosial yang akhirnya mendorong sikap untuk berperilaku anarkis.

Pesatnya pertumbuhan kawasan industri di wilayah Kota Cilegon juga berpengaruh sangat besar pada penataan lahan, serta dinamika sosial kemasyarakatan selama kurun waktu 1980an-sampai sekarang. Lingkungan pun turut terganggu, seperti ruang terbuka hijau yang tidak optimal, hutan kota, serta menurunnya kualitas lingkungan akibat pencemaran limbah industri yang melampaui standar mutu penataan kawasan lingkungan. Keadaan ini diperkuat dengan pernyataan (Halusi, Lurah Katileng Cilegon) bahwa polusi udara dan air dari limbah industri. Pembuangan sampah ilegal yang sangat membahayakan penduduk, seperti di wilayah lingkaran selatan kecamatan Citangkil, seperti asap dari industri kimia yang menutupi jalan, serta debu-debu yang dihembus dari mobil truk perusahaan di sepanjang jalan industri Cilegon.

Berkaitan dengan dampak industri terhadap lingkungan sekitar, rekomendasi strategi pengelolaan kawasan industri menuju eco industry park/kawasan industri hijau, yang disitir dari tulisan Fatah Sulaiman (2009) yaitu dengan memprioritaskan 6 (enam) standar, yaitu:

a. Pembangunan instalasi pengolahan limbah.

b. Penyediaan ruang terbuka hijau, minimal $30 \%$ dari kawasan industri yang digunakan.

c. Penegakan implementasi hukum yang tegas terhadap pelanggaran atau 
perundang-undangan terkait kawasan industri.

d. Pemberian sanksi bagi industri yang tidak memperhatikan lingkungan.

e. Membentuk kelembagaan khusus untuk mengelola kawasan industri hijau.

f. Mempertahankan daerah resapan air untuk menjamin ketersediaan air bagi kelangsungan operasional perusahaan yang digerakkan langsung oleh pemerintah setempat untuk dibuat peraturan walikota setempat (Perwal).

Optimalisasi keterlibatan, kontribusi dan partisipasi perusahaan terhadap pembangunan masyarakat setempat, menjadi faktor utama bagi keberlanjutan perusahaan. Sinergi yang terjadi antar masyarakat dan perusahaan menjadi penunjang keberhasilan sebuah perusahaan yang berada di kawasan industri. Apalagi sudah menjadi keharusan perusahaan, terutama yang berada dekat pemukiman warga, secara langsung mereka merasakan dampaknya dari keberadaan kawasan industri, dan diperkuat pula oleh ketetapan UU pemerintah mengenai kegiatan CSR perusahaan.

Seperti terurai dalam Undangundang No. 40 Tahun 2007 mengenai tanggungjawab sosial dan lingkungan perseroan terbatas, dan PP 47 Tahun 2012 mengenai tanggung jawab sosial dan lingkungan Perseroan Terbatas. Dalam undang-undang ini diatur mengenai tanggungjawab sosial dan lingkungan bertujuan mewujudkan pembangunan ekonomi yang berkelanjutan guna meningkatkan kualitas kehidupan dan lingkungan yang bermamfaat bagi perseroan itu sendiri, komunitas setempat, dan masyarakat umumnya. Ketentuan ini dimaksudkan untuk mendukung terjadinya hubungan perseroan yang serasi, seimbang, dan sesuai dengan lingkungan, nilai, norma dan budaya masyarakat setempat maka ditentukan bahwa perseroan yang kegiatan usahanya dibidang dan/atau berkaitan dengan sumberdaya alam wajib melaksanakan tanggungjawab sosial dan lingkungan. (Yusuf, 2007)

Kesejahteraan sosial merupakan kondisi sejahtera dari suatu masyarakat, meliputi kesehatan, keadaan ekonomi, kebahagiaan dan kualitas hidup rakyat. Kemakmuran rakyat yang lebih diutamakan dari pada kemakmuran perseorangan, fakir miskin dan anak-anak terlantar dipelihara oleh negara. Dalam hal ini industrialisasi sebaiknya memperhatikan kesejahteraan sosial yang menjadi masalah dan mendapatkan perhatian utama dan menjadi tanggung jawab bersama. Hal ini dapat terwujud apabila masing-masing individu 
memiliki kesadaran untuk senantiasa memprioritaskan kepentingan bersama, agar kesejahteraan sosial dapat terwujud dan dirasakan oleh setiap lapisan masyarakat, (Julianti, 2012).

Namun bila ditinjau dampak keberadaan industri terhadap budaya masyarakat, tidak dapat dipungkiri dari data penelitian yang diperoleh dari responden yang tinggal di area kawasan industri kota cilegon, menunjukkan bahwa terwujudnya kemajuan di bidang material dengan keberadaan kawasan industri pada kenyataannya berbanding terbalik dengan merosotnya nilai-nilai moral, kebudayaan dan agama. Kemajuan teknologi dengan sokongan kapitalisme hadir untuk membantu manusia mengisi kekosongan dalam kehidupan pribadi. Orang-orang kemudian menghabiskan uang dari hasil kerjanya di tempat-tempat yang telah disiapkan untuk menghilangkan kepenatan, diantaranya tempat rekreasi, game zone, shooping center dengan aneka macam barang pilihan yang pasti akan mendorong masyarakat pada posisi konsumen dari apa yang mereka produksi sendiri. Banyak masyarakat yang kemudian terjebak dalam gaya hidup (life style) konsumtif dan hedonis, sehingga secara tidak sadar menjadi objek pasar. Terkait hal tersebut, Nurcholish Madjid dalam Ibrahim (2010) menyatakan bahwa untuk menjadi masyarakat industrial, masyarakat harus disiapkan menerima nilainilai yang bakal menunjang proses industrialisasi, dikehendaki ataupun tidak pasti melahirkan tata nilai yang kebanyakan tidak dikenal oleh masyarakat pedesaan.

Sedangkan harapan-harapan masyarakat dengan adanya kawasan industri di sekitar masyarakat, terdapat prioritas kebutuhan yang dapat dipenuhi perusahaan, antara lain:

a. Perusahaan mampu meningkatkan kesejahteraan sosial, antara lain: peningkatan taraf hidup, kesehatan, pendidikan, dukungan beragama, nilai moral, dan pendukung aspek kesejahteraan sosial lainnya.

b. Perusahaan mampu menyediakan lapangan kerja dan peluang berusaha.

c. Perusahaan mampu meningkatkan penyediaan fasilitas pendidikan, perumahan, dan fasilitas umum.

d. Perusahaan mampu meningkatkan jaminan hukum, ketertiban dan keamanan.

e. Perusahaan dapat melakukan penanganan lingkungan hidup yang lebih bijaksana, agar masyarakat dapat merasakan hidup aman dan nyaman tinggal dan berdekatan dengan kawasan 
industri.

Namun sampai saat ini, menurut mayoritas responden menyatakan perusahaan belum memenuhi harapan warga sebanyak 58\%. Namun sebagian lainnya, pihak perusahaan sudah memenuhi harapan warga diantaranya PT Krakatau Steel beserta anak cabangnya, yang membantu penyediaan air bersih dengan membangun sumur artesis, memberikan dana pendampingan usaha dalam bentuk kemitraan, penghijauan agar dapat meminimalisir debu masuk ke rumah warga dan dapat mengakibatkan sesak napas atau ISPA, Sekolah terpadu, dan sebagainya.

\section{KESIMPULAN DAN SARAN}

\section{Kesimpulan}

Berdasarkan hasil kajian dampak sosial keberadaan industri terhadap masyarakat sekitar kawasan industri Kota Cilegon, dapat diambil kesimpulan sebagai berikut:

1. Kota Cilegon sebagai daerah tujuan investasi memiliki daya tarik bagi investasi dalam dan luar negeri. Hal ini dapat dilihat dari tingginya minat investor, ditunjang dengan sarana prasarana yang cukup memadai, serta letak geografis yang sangat strategis. Kota Cilegon sebagai pintu gerbang pulau Jawa dan Sumatera, serta memiliki garis pantai sepanjang $17 \mathrm{~km}$, didukung oleh pelabuhan bertaraf internasional dan adanya pelabuhan khusus, serta beberapa kawasan industri menjadikan Kota Cilegon sebagai tujuan investasi yang menarik bagi calon investor. Kota Cilegon terbuka untuk investasi bidang usaha besi dan baja, kimia, plastik, manufacture, pariwisata, usaha aneka dan jasajasa lainnya. Dengan demikian untuk menarik investor tersebut Pemerintah Kota Cilegon dengan PT. Krakatau Steel dan perusahaan lainnya menyediakan berbagai sarana prasarana pendukung untuk kegiatan investasi terutama dalam menyiapkan kawasan industri. Selain itu, untuk membantu pemberdayaan usaha kecil dan menengah yang ada di Kota Cilegon agar berkelanjutan, dibentuk beberapa lembaga ekonomi untuk memfasilitasi permasalahan di bidang permodalan, managemen dan pemasaran.

2. Di kawasan industri kota Cilegon, keberadaan kawasan industri disambut baik oleh masyarakat. Perusahaan yang ada mempunyai perhatian terhadap pengusaha kecil menengah untuk menjaga keberlanjutan usaha, dengan 
dana pendamping atau kemitraan.

Peluang usaha dan kesempatan kerja semakin terbuka, dan penataan lingkungan yang lebih baik. Sedangkan dampak negatif yang dirasakan masyarakat, dengan adanya kawasan industri di tengah-tengah pemukiman mereka, banyak pendatang yang mengadu nasib di wilayah cilegon sehingga tingkat persaingan angkatan kerja masyarakat sekitar semakin tinggi, penurunan kualitas lingkungan, serta kemacetan lalu lintas membuat masyarakat terganggu. Di samping itu, beragamnya para pendatang sulit membendung terjadinya pergeseran nilai-nilai luhur budaya masyarakat setempat.

\section{Saran}

Saran yang dapat diberikan terkait dampak sosial keberadaan industri terhadap masyarakat sekitar, yaitu:

1. Pendatang dari berbagai luar daerah dan negara asing, menjadi ancaman bagi masyarakat untuk mendapatkan pekerjaan. Oleh karena itu, pemerintah menetapkan perusahaan memprioritas angkatan kerja setempat, untuk melaksanakan program latihan kerja, agar para pekerja memiliki keahlian dan keterampilan yang mampu memenuhi kebutuhan perusahaan.

2. Pengusaha kecil menengah relatif berjalan stabil, namun untuk meningkatkan hasil usaha, kualitas pemasaran dan produksi, diperlukan dana bantuan pendampingan atau kemitraan. Pihak perusahaan memberikan kesempatan seluasluasnya kepada para pengusaha yang ingin melakukan pengembangan usaha, dan memberikan bantuan pendamping dana.

3. Untuk mengurangi kriminalitas, aparat pemerintah di wilayah setempat bekerja sama untuk menekan kasus kriminal yang terjadi di kawasan industri. Di samping itu, agar para generasi muda dapat memanfaatkan waktunya untuk berorientasi pada kegiatan lebih positif, perlu dilakukan pembinaan kelompok-kelompok remaja, dengan mengembangkan kegiatan bakat seni dan olah raga secara berkesinambungan.

4. Perusahaan berkontribusi dalam pengadaan sarana prasarana publik menjadi lebih layak, adalah faktor utama yang tidak kalah pentingnya, seperti taman bermain, lembaga pendidikan dan layanan kesehatan, dan 
sebagainya.

5. Penataan lingkungan di sekitar kawasan industri, agar tertata dengan baik, penerapan eco industry atau kawasan industri hijau merupakan kewajiban yang harus dilaksanakan oleh perusahaan. Hal ini dilakukan agar lingkungan tidak tercemar, kehidupan masyarakat tidak terganggu dari polusi udara, air, tanah, dan kemacetan lalu lintas.

\section{DAFTAR PUSTAKA}

Ibrahim, M.M. 2010. Masyarakat Industri. Masalah Fakultas Humaniora dan Budaya UIN Malang.

Julianti. 2012. Kehidupan Sosial dan ekonomi Penduduk Asli Pasca Konversi Lahan oleh PT. Inco Tbk (Studi Kasus Desa Sorowako Kecamatan Nuha Kabupaten Luwu Timur Provinsi Sulawesi Selatan).

Milles, M.B. and Michael A. Huberman. 1992. Analisa Data Kualitatif. Jakarta: UI Press.

Profil Kota Cilegon. 2016. Peluang dan Investasi Kota Cilegon

Sugiyono. 2013. Metode Penelitian Manajemen, Pendekatan: Kuan-titatif, Kualitatif, Kombinasi (Mixed Methods), Penelitian Tindakan, Penelitian Evaluasi. Bandung: CV Alfabeta.
Sulaiman, F. 2009. Disertasi: Pengelolaan Kawasan Industri Menuju Eco Industrial Park (Studi pada Kawasan Industri Cilegon Propinsi Banten). IPB, Bogor.

Yusuf, W. 2007. Membedah Konsep dan Aplikasi CSR. Gresik. Fascho Publishing. 
Sekitar Kawasan Industri Cilegon - Yunia Rahayuningsih 